\title{
Old Threats, New Approach and National Security in Malaysia: Issues and Challenges in Dealing With Cross-border Crime in East Coast of Sabah
}

Ramli Dollah

\author{
Wan Shawaluddin Wan Hassan
}

Diana Peters

Zaini Othman

Faculty of Humanities, Universiti Malaysia Sabah, 88400 Kota Kinabalu, Sabah, Malaysia

\author{
Doi:10.5901/mjss.2016.v7n3s1p178
}

\begin{abstract}
For centuries there has been the free movement of people and goods across North Borneo to its neighbouring countries, primarily Indonesia and Philippines. However, when Sabah gained independence through the formation of Malaysian in 1963, such activities which were previously considered legal, are now labeled as smuggling and illegal entry, and are thus an existential security threat to Malaysia. Porous and an extremely long border have made it difficult for the state to address the rise of these incidents. The intrusion of Sabah by members of so-called the Royal Sulu Army in 2013 was the last straw. The incident drove the government to establish a civil-military command known as Eastern Sabah Security Command (ESSCOM). It was an organization under which all enforcement agencies such as police, army, immigration, marine, coast guard etc, will be coordinated under one command system. The objective of this study is to identify the measures and challenges for ESSCOM and Malaysian government in dealing with Sabah's East Coast of maritime security. The review will be mainly focused on the nature of the threat, the reasons for the ESSCOM establishment and policy measures taken to strengthen Sabah's maritime security.
\end{abstract}

Keywords: Malaysia, Sabah, Security, Military, Non-Traditional

\section{Introduction}

Sabah is one of 13 states in Malaysia located on the island of Borneo which is strategically located and shares its borders with three countries - Indonesia, the Philippines, and Brunei. There are various threats to the survival of this state, especially in the east coast of Sabah, which involve traditional threats such as continuous territorial claims by Manila, and also non-traditional threats such as kidnapping, trafficking, and illegal immigrants. This paper will focus on non-traditional threats in Sabah as well as policies and measures that have been taken to address the problem. This paper will also delve the Tanduo incident which eventually led to the establishment of the Eastern Sabah Security Command (ESSCOM). In addition, a number of issues and challenges will also be discussed to enable us to understand this issue in greater detail. Discussion in this paper will be divided into several sections, the first focuses on a brief background of Sabah; second, identifying the threats, either traditional or non-traditional threat facing the state; third, focusing on the effort to counter such threats and establishment of ESSCOM, fourth, focuses on the measures by the ESSCOM to strengthen Sabah's maritime security by looking at the several policies that has been undertaken and finally addressing the problems and challenges by the ESSCOM and the Malaysian government in dealing with the problem of maritime security in the East Coast of Sabah. It concludes that to boost the security along the coastal lines of Sabah were just one part in tackling cross-border maritime issue between Sabah and its neighboring countries. Therefore, the government has to look into other possibilities by focusing more on the 'software' aspect (which is non-military approach) of security, instead of focusing more on the 'hardware' aspect which is military in nature in managing maritime security issues in the east coast of Sabah. 


\section{Sabah Background}

Historically Sabah ${ }^{1}$ (formerly known as North Borneo) is the second largest state in the Malaysia Federation and is located in Eastern Malaysia. Before joining the federal government in 1963, the state was under the British government. It is noteworthy to mention that the state is the product of 65 years of Chartered Company rule and 17 years of British Colonial administration. This began in 1881 when the state was under the British North Borneo Chartered Company (BNBC). In 1888, it became one of the protectorates of the British colonial administration but was maintained under BNBC administration. However, after the Pacific War (1946-1963), it came under direct British colonial rule (Tregonning, 1965). On 31 August 1963, less than 16 days before the formation of Malaysia, the British granted the status of the selfgovernment to Sabah.

Sabah covers $72,689 \mathrm{~km}^{2}$ of land (this does not include the land area of the islands which represent approximately $1,549 \mathrm{~km}^{2}$ ), while its maritime area covers $54,360 \mathrm{~km}^{2}$, constituting 30 percent of the Malaysia's Economic Exclusive Zone (EEZ). It stretches from the South China Sea in the west and the Sulu Sea to the north of Kudat and extends to the eastern coast, covering the Sulu Sea, and the Celebes Sea in the districts of Semporna and Tawau. The marine coastal zone is delimited by the interstate boundary of Sarawak and international boundaries of Brunei, Indonesia and the Philippines. According to the official government sources of Sabah, the major part of the area lies in the South China Sea extending to the limit of the continental shelf off the West Coast of Sabah. To the Southeast, off the East Coast of Sabah between Semporna and Pulau Sebatik, the area again extends to the continental shelf boundary in the Celebes Sea. The remaining part of the area between Semporna and Kudat lies in the Sulu Sea with the boundary being the Malaysia/Philippines international boundary. Around 30 percent of the marine coastal zone areas, or approximately $54,360 \mathrm{~km}^{2}$, are the territorial waters of Sabah.

\section{Defining Security}

Traditionally, the threat to national security was perceived to be generated externally, specifically those associated with military threats to the state, territorial integrity, and political independence. Having such conceptions, it cannot be avoided that most of the definitions of security place the issues above as a core of national security concern. ${ }^{2}$ In the national security concept, the state is the key actor because it has legitimate force in society and represents the greatest concentration of power, in particular having legitimacy to use military force to protect its sovereignty; it has instruments of force to use both domestically and externally. The most important task of the state is to provide security and protect its citizens against internal and external threats. Indeed defending a country against military threats has traditionally been considered the greatest duty of government (Buzan et. al, 1998: 51). Giving the state such a responsibility, it is not surprising that the conception of national security is closely tied to military capability. Although it is recognized that military threats are not the only challenges to national survival as other threats to states may be even more severe, military force remains crucial to the maintenance of national security. ${ }^{3}$

The narrow and traditional definition of national security being advocated by Walt, stresses security as the study of threat, use, and control of military force with the emphasis being on examining the causes, consequences, and resolution for war and on explaining how national governments use military forces effectively to cope with foreign military threats (Walt, 1991). However, in practice, the military security agenda revolves largely around the ability of governments to shield themselves against internal and external military threats though it can also involve the use of military power to defend states or governments against non-military threats, such as migration or rival ideologies (Buzan et. al, 1998: 51). Nevertheless, since the 1980s this narrow interpretation of security is being challenged by new concepts of security. Looking at these new challenges, many suggested that non-military threats should be included under the rubric of national security so as to include other issues such as the economy, poverty and the environment (Ullman, 1983: 129135; Kolodziej, 1992: 421-438; Buzan, 1991). In Sabah, it is this non-traditional threats that pose the greatest challenge to the state's security compared to the traditional concept of security. This is evident when we look at the threats

\footnotetext{
1 The term 'Sabah' or 'Saba' was given by the Brunei and perhaps derives from Biblical name (Tregonning, 1965: 16).

${ }^{2}$ According to Hans Morgenthau 'National security must be defined as integrity of the national territory and its institutions'. For Azar and Moon, national security covers a broad of spectrum of vital interest such as organic survival of a given national population, protection of sovereignty, well being of citizens, and political status and prestige (Morgenthau, 1960: 562; Azar and -In Moon, 1984: 109).

${ }_{3}^{3}$ However, Park and Park contended that there is a more serious problem if one to define national security only in quantitative terms. By evaluating non-material aspects of national security, they demonstrated how self-reliance constitutes part of national security (Park and Park, 1988).
} 
emanating from non-state actors such as terrorism, Kidnapping for Ransom $(K f R)^{4}$, armed robberies, piracy and so on as will be discussed in the following section. Therefore, this paper argues that these new type of threats to national security cannot be managed by traditional military policy alone because it also requires a non-military approach to deal with such threat.

\section{Non-Traditional Threats in East Coast of Sabah}

The main issues in the east coast of Sabah revolve around non-traditional threats from non-state actors. Therefore, cases of kidnapping and robberies by armed groups are rampant in Sabah. It is not a new issue since such incidences also occurred in Sabah when it was under colonial rule. During the armed robberies in the Lahad Datu district in 1984 and also in the Semporna district in 1996 for example, a group of gunmen, believed to be a group of Filipino pirates, attacked the police station and military outposts in these districts causing the injury and deaths of several local people. In 2000, two more serious incidents took place in Sabah when a group of people from the Philippines identifying themselves as the Abu Sayyaf group (ASG) abducted foreign tourists in the Sipadan and Pandanan islands. The first occurred on April 23, 2000, when the ASG, using small boats (called Tempel among Filipino), armed with Bazooka and M16 abducted 10 Malaysian workers and 11 foreign tourists (Polumpung, 2002). The ASG made various demands for the release of the hostages including, the separation of southern Philippines administration from the central government of Manila, the establishment of an Islamic state in Mindanao, US\$1 million ransom for each victim and involvement of the OIC and the UN in negotiations. The ASG also put forward several demands among those was the establishment of a commissioner to look after the rights of refugees in Sabah (Berita Mingguan, 30 Apr. 2000; Utusan, 30 April 2000; NST, 30 April 2000). The group finally offered to release all hostages on April 28, 2000 (Utusan, 19 August 2000; Berita Harian, 19 August 2000; Mingguan Malaysia, 19 August 2000). It was believed that millions of dollars had been paid to the ASG for the release of 20 victims from the Sipadan incident. Libya itself, the main negotiator in this incident, was said to have paid US\$20 million to release all hostages (Desker and Ramakrishna, 2002: 165).

The second kidnapping at Pandanan Island took place on September 11, 2000, when members from the same group, armed with M16 and two speedboats, kidnapped three Malaysians off a resort; only a few kilometers from the Sipadan island (Ramli, 2004 and Polumpung, 2002). Their modus operandi was similar to the previous one in which ASG made demands for the government to pay ransom for the release of all hostages. However, following the major military operation by the Philippines army in the ASG stronghold, Jolo, in October 2000, all hostages were rescued (For details see, Liss, (2010: 237-268); Ramli, (2004); Peters \& De Silva, (2002); Che Moin Umar, 2002 and 2002a). In October 2003, another incident took place in the Borneo Paradise Eco Resort Farm (BPERF), Lahad Datu when a similar group kidnapped five BPERF employees. Similar to the Sipadan and Pandanan hostage-taking incident, the group demanded a ransom for the release of all victims. All hostages were eventually released after a Miri-based shipping company paid the ransom.

Apart from the threat posed from KfR, another major threat to Sabah's security is associated with the presence of the terrorist-linked group. This was based on the Indonesian intelligence information which claimed the most wanted individuals such as Nordin Top and Azahari were roaming freely between the Indonesian-Malaysia-Philippines territory of Kalimantan, Sabah and Mindanao (the Southern Philippines) (Abuza. 2003: 46). Hambali, the JI prominent leader revealed that since 2003 , the organization had transferred more than US\$27,000 money to the MILF. More alarming was when it claimed that some of the $\mathrm{Jl}$ members open bank accounts in Malaysia, deposit funds, and then hand over ATM cards to MILF operatives based in Sabah (Abuza. 2003: 46). This was based on information gathered during interrogation on Darul Islam members detained in Sabah, another extremist group believed to aspire in establishing an Islamic state in this region. Eventually, the Counter Terrorism Officer (СTO) revealed that the existence of the JI movement in Sabah can be traced back to the late 1980s. This revelation triggered the government to take serious counter measures (see, for example, M. Shah Hussin Shah, 2006: 110). Apparently, this pattern of the JI activities in Sabah emerged during interrogation of Nasir Abbas, the head of Mantiqi III, which covered the areas of Brunei, Sabah, the southern Philippines, and Sulawesi and Kalimantan (Indonesia) (For comprehensive view on the JI organization, see Nasir Abas, 2005); Singapore Government, 2003) and Desker, 2003: 409-507; Atran, 2005: 78-80). Nasir, a Singaporeborn Malaysian captured by Indonesian police in April 2003, told investigators that weapons and explosives used by his group were obtained from Zamboanga in the southern Philippines, which is also the stronghold of the Moro Islamic Liberation Front (MILF). The intelligence claims that based on Nasir confession, Sabah is a susceptible to the terrorists

${ }^{4}$ For a more detailed work on KfR particularly in Southeast Asia please refer to Mohd Kassim (2008): 61-73; Storey (2008): 95-128; Thayer (2003) 
activity.

The weapons and explosives were ferried by boats to Tawi-Tawi, then to Sandakan ... They were then taken over land to Tawau... JI members also used the sea route from Tawi-Tawi to Sandakan ... JI also used public transport to smuggle the weapons and explosives ... into Nunukan, a border town on the Nunukan Islands in East Kalimantan ... They used public transport to avoid detection of their activities by the authorities.

(Chua, 21. Aug. 2003)

\section{What Measures Has been Taken to Boost Sabah's Security}

Following the Sipadan and Pandanan incidents, the government responded immediately and launched a major operation codenamed Ops Pasir (Pandanan and Sipadan) in September 2000 with the deployment of security forces at strategic spots. It was a major operation in Sabah combining all branches of Malaysian security forces such as the Police and the Armed Force. Its main purpose was to boost security in the Sabah's territorial waters especially to avoid intrusion, piracy, terrorism and any other cross-border elements. Under this operation, the Army had mobilized almost 200 of its Special Force (PAC) and almost 600 personnel to tighten the security in Sabah territorial waters. Meanwhile, the General Operation Force (GOF), one of the branches under the Malaysian Royal Police (previously called Jungle Squad) had deployed 5 battalions to boost security in this area. Over 1,000 GOF personnel were stationed in 23 posts in islands and 35 in the coastal area. In the district of Semporna, for instance, GOF was stationed in 16 outposts such as Sipadan, Mabul, and Si Amil islands. ${ }^{5}$ The operation also included over 100 of Special Force personnel and about 40 combatant boats. Additionally, the police air unit supported by 6 surveillance aircraft had mobilized 30 of its vessel and 17 patrol boats in Sandakan, Tawau, and Semporna (Musa Aman, 02 Nov. 2000). The navy was also involved with 30 ships and boats, as well as 2 teams of special forces, while the air force deployed six aircraft, including 3 Hawk jets fighter. Shafie Apdal, Deputy Minister of Defence in 2001 announced that as a result of this operation, over 790 boats were detected and out of these 174 boats were detained, 4,697 people were checked and many were arrested including 40 Malaysian, 505 Indonesian and 1,070 Filipino and 31 others, mostly illegal immigrants or suspected extremist group members (Mohd. Shafie Apdal, 31 May 2001). It was later revealed in 2010 that the cost for executing Ops Pasir cost more than RM300 million annually (Malay Mail, 27 Jan. 2010).

The government also strengthened and widened its border patrol area. Among measures taken was the implementation of seven designated lanes for commercial vessels or passenger boat into Sabah waters. This policy effectively came into force on $1^{\text {st }}$ April 2002 which included areas such as Kota Kinabalu, Tawau, Lahad Datu, Labuan, Kudat, Semporna and Sandakan. Through this policy, several previously favored routes like those through Nunukan Island in Indonesia to Tawau via Wallace Bay was no longer available. All vessels were not allowed to travel outside of the designated route and failure to comply with the policy would be regarded as a serious offence (Sabah Times, 09 Jan. 2002; New Straits Times, 05 Dec. 2001; New Straits Times, 04 Jan. 2002; New Straits Times, 02 Mar. 2002). Meanwhile, for foreign merchant's vessels involved in barter trading in Sabah, the government identified several points where they were required to leave their arms before entering Sabah's territory. Vessels which failed to comply with this requirement would be subject to heavy punishment (Mohd. Shafie Apdal, 13 Dec. 2000). The main purpose of this policy was to ensure the effectiveness of enforcement agencies to monitor the movement of people between Sabah and neighboring countries and to ensure Sabah's security.

In line with these policies, the government also decided to ban the uses of pump boats in April 2002 to avoid any intrusion by outside elements (NST, 23 Feb. 2002; NST, 02 Apr. 2002; Berita Harian, 26 Aug. 2002). The Pump boat is a small boat powered by motorized water pumps and very popular among dwellers in the coastal area. However, it was frequently used by criminal perpetrators in Sabah waters, especially immigrants, and extremist group because of its maneuverability in shallow waters, thus avoiding detection or arrests by the Malaysian security agencies (See Ramli Dollah et. al. 2003).

This incident had also forced the government to place more emphasis on strengthening the role of the Malaysian navy especially in the vulnerable point of eastern part of Sabah (MMEA, 2015). The government moved to set up a new Navy submarine base in Kota Kinabalu and the PASKAL base (Special Force unit for Navy) in Semporna, as well as announcing a proposal to set up a new air base in Tawau (Najib Razak, 09 Apr. 2001). In fact, in 2010, the government publicly revealed that in order to prevent a similar incident, the government had spent millions of ringgits to ensure Sabah and Malaysia security, 'Security operations to prevent a repeat of the Sipadan and Pandanan hostage incident had taken

${ }^{5}$ Meanwhile, Army had deployed in several other islands and coastal areas such as Danawan, Sibuan, Boheyan, Roach Reef, and Kapalai. Interview with Senior Police Officer 
a huge toll on our national security budget' (Malay Mail, 27 Jan. 2010).

To ensure the effectiveness of security in the Malaysian territorial waters, Sabah in particular, the government on 21 August 2002 decided to establish the Malaysian Maritime Enforcement Agency (MMEA) or the Malaysian Coast Guard (Mohamed Nazri Aziz, (16 Jun. 2006). In terms of allocation, until May 2006, the government has spent around RM176 million for the MMEA. Meanwhile, for the same period, around RM132 million has been spent to strengthen the MMEA management and development (Nazri Aziz, 18 Dec. 2006; A. Rahman Sulaiman, 05 Jul. 2006 and Mashita Ibrahim, 23 Jul. 2008). In 2010, the government reveals that the cost for maintenance of MMEA is over RM100 million annually (Malay Mail, 27 Jan. 2010). Clearly the establishment of this maritime agency which cost millions of ringgit could not be realized without the context. Therefore, even though the MMEA only formally established through the enactment of the Malaysian Maritime Enforcement Agency Act 2004 (Act 633), the justification for the agency's establishment came during the period when Malaysia was threatened by the issue of terrorism, illegal immigrants and extremist group. This perception of the governing elites indicates the seriousness of the issue to Malaysia's security and Sabah in particular.

\section{Tanduo Incident and Establishment of ESSCOM}

The Tanduo incident started when an armed group arrived by boats in Tanduo, Lahad Datu, Sabah on February 11, 2013. The group, identifying themselves as the 'Royal Security Army' (RSA), was reportedly sent by Jamalul Kiram III, self-proclaimed Sultan of Sulu. Their main objective was to reclaim Sabah from Malaysia. Malaysian security forces cordoned the area where the group had gathered and after several days of failed negotiations, finally decided to use force to neutralize the threat. On March 1, 2013, three days after Malaysia's extended deadline for the group to leave the area peacefully, a confrontation occurred between Malaysian forces and the group. Two Malaysian police lost their lives while 10 members of the RSA group were killed with four more injured. Following the shootout, Najib announced that the Malaysian security forces were given the mandate to take 'any action' to deal with this militant. On March 3, 2013, another incident took place in Kampung Sri Jaya Siminul in Semporna, some $200 \mathrm{~km}$ from the Tanduo when Malaysian police were attacked by an armed group believed to be the same group in Tanduo. In the incident, six Malaysian police officers and seven militan members were killed.

After a three-week standoff, the Malaysian armed forces started their massive campaign by launching air strikes. On March 5, 2013, Royal Malaysian Air Force F/A-18 and Hawk fighters bombed the militant position in Tanduo. This was followed by the clean-up operations codenamed "Ops Sulu" (referring to Suluk community). It was later changed to "Ops Daulat" (Operation Sovereignty) due to ethnic sensitivity in Sabah. During the crackdown, the Malaysian forces recovered 22 bodies of suspected Kiram followers. However, Agbimuddin Kiram, the leader who led the armed incursion and several of his members had managed to escape. On 11 March, Tanduo village was declared secured by Malaysian security forces after a week of air operations.

Following the intrusion Tanduo, on March 7, 2013, Prime Minister, Najib Razak during his visit to Lahad Datu, declared the east coast of Sabah as "Special Security Area" (SSA). However during the Sabah's State Security Committee meeting chaired by the Sabah Chief Minister, Musa Aman on March 11, the SSA was changed to the Eastern Sabah Security Command (ESSCOM) (Borneo Post, 12 March 2013) with its headquarters based in Lahad Datu. The ESSCOM operations will cover the area of the eastern coast of Sabah from northern Kudat to southeastern Tawau. The ESSCOM combines several enforcement agencies such as the Malaysian Armed Forces (ATM), Royal Malaysia Police (PDRM), Malaysian Maritime Enforcement Agency (MMEA), Royal Malaysian Customs and Immigration under one command system. ESSCOM will be responsible for coordinating operations, intelligence gathering etc to ensure safety and secure the waters off Sabah from external threats (ESSCOM Times, 2015).

On March 25, 2013, Najib Razak announced the creation of the Eastern Sabah Security Zone (ESSZONE) which will cover 10 districts in the East Coast such as Kudat, Kota Marudu, Pitas, Beluran, Sandakan, Kinabatangan, Lahad Datu, Kunak, Semporna and Tawau (ESSCOM Times, 2015). The entire area covers approximately around 52,262.90 $\mathrm{km}^{2}$ (James Collins, Ramli Dollah \& Zaini Othman (2014)). 


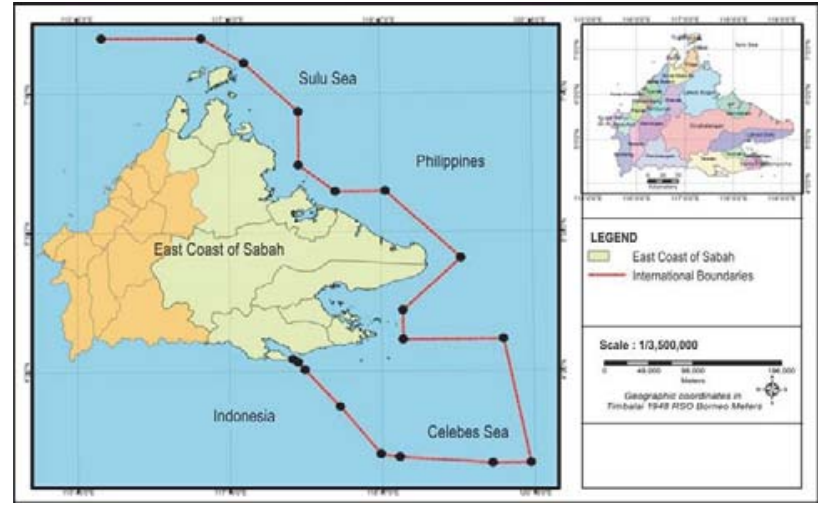

Figure 1: The Location of East Coast of Sabah

Source: Collins, et. al. (2014)

In order to strengthen ESSCOM and to ensure the success of the organization, the government in April 2013 outlined a four-pronged strategic and technical approach to beef up security in national waters, to provide protection to the ESSZONE community. The four elements are: first, enhancement of intelligence capability; second, effective coastal surveillance 24-hours a day; third, boosting the country's capability to intercept incoming threats from the sea; and fourth, strict enforcement of the law with immediate action taken once the threats reached the shores (Daily Express, 14 Apr. 2013).

The government also took additional measures to further increase security in the area. In the 2014 budget, for example, ESSCOM obtained an additional allocation of RM75 million for its administrations and RM2.4 million for the purchase of defense equipment. Meanwhile in the 2015 budget, the government allocated RM17.7 billion to the Malaysian Armed Forces (ATM), and RM9.1 billion for the Royal Malaysian Police. A total of RM804 million was allocated to the Malaysian Maritime Enforcement Agency (MMEA) to strengthen maritime enforcement (Najib Abdul Razak, 10 October 2014: 51). The government also allocated RM660 million to set up two new battalions of PGA camp in ESSZONE and another Army battalion camp will be set-up in Felda Sahabat in Lahad Datu (Najib Abdul Razak, 2014: 34). In order to boost the Malaysian enforcement agencies capability especially to provide prompt respond for any intrusion, the government has allocated RM230 million for the use of a modified oil platform and an auxiliary vessel as seabasing in the ESSZONE through its wholly-owned oil and gas company Petronas, through its social responsibility program. The government also decided to upgrade the airport runway in Lahad Datu to cater high capacity of aircraft in this area. The government has also transferred Squadron Hawk from Butterworth, Penang to Labuan with an allocation of RM50 million.

However, despite the efforts taken to strengthen ESSCOM's capabilities, it was unable to prevent cross-border kidnappings or KfR. On 15 November 2013, for example, Filipino gunmen shot and killed a 57-year-old Taiwanese tourist Hsu Li Min and abducted his 58-year-old wife Chang An Wei at Pom Pom Island Resort. The gunmen were believed to have arrived in a group of eight via a speedboat from the neighboring southern Philippines (The Star, 18 Nov. 2013). Chang was later released in December after a ransom was paid to the kidnappers (Astro Awani, 29 Sept. 2014; Harian Metro, 29 September 2014). A Taiwanese newspaper estimated that RM80, 000 (12 million pesos or 8 million Taiwan dollars) ransom had been paid for her release (The Rakyat Post, 21 Dec 2014). Another abduction by seven armed men occurred on 2 April 2014, this time from Singamata resort, Semporna, involving a Chinese tourist and a Filipino worker. Kidnappings continue to occur despite the presence of enforcement agencies in the ESSZONE. On May 7, 2014, for example, a Chinese citizen who was also a fish farming manager in the Pulau Bait, Lahad Datu was kidnapped by a group of five armed men believed to be the same group of KfR (The Star, 07 May 2014).

On June 16, a group of gunmen attacked a fish farm in Kampung Sapang, Kunak and kidnapped the manager, Chan Sai Chuin. More worrying, not only tourists who become the target of this group but also police personnel also fall victim to these armed groups. For example, on July 12, 2014, Corporal Ab Rajah Jamuan was shot dead while his colleague Constable Zakiah Aleip, was taken from a resort in Sipadan Water Village Resort, Semporna. Following the incident, the government resorted to enforcing a 7pm-5am curfew in six coastal areas in the east coast to curb the presence of these armed groups. The curfew, which takes effect in the waters of ESSZONE, has been going on since 
July 19,2014 , aims to enable the authorities to regulate this area more closely in order to avoid kidnappings in the area. Today, this curfew has taken $31^{\text {st }}$ phase since it first implemented last year (Borneo Post, 9 November 2015).

\section{Issues and Challenges}

Although numerous measures have been taken by the government to address the problems of cross-border crimes has been difficult to resolve. One of the main reasons has been due to geographical factors such as Sabah's vast land area, long porous borders, the presence of many islands in Sabah's waters and its close proximity to 'troubled' neighboring countries especially Indonesia and the Philippines. The landscape of Sabah, with the length of the Sabah coastlines around 1,448 kilometers, stretches from the South China Sea, and the Sulu to the Celebes sea makes it very difficult to prevent sea robberies or cross-border criminals from slipping into Sabah. Even if the government increases the number of personnel and patrols since Sabah's long coastlines and the presence of hundreds of islands in Malaysia-IndonesiaPhilippines waters make it very difficult to patrol the Sabah maritime territorial water effectively. In Semporna, for example, the presence of many tiny islands such as Kapalai, Maiga, Bohey Dulang, Mataking, Pandanan etc make it easy for the gunmen to slip into Sabah. In addition, it was also believed that the gunmen would use any of the 107 islands or islets in Tawi-Tawi as a staging point before entering Sabah (The Star, 22 June 2014). When this group reaches Sabah's waters, they can use all these islands as a means of shelter, escape or hideout from Malaysia's security forces before they reach the mainland.

In addition, it is also understood that the group employed new technology to avoid being detected by the police, marines or other enforcement agencies. One such example was the uses of technology that could silence or reduce engine noise. Therefore, the government also admitted that some of the immigrants and KfR use up-to-date, modern and upgraded technology compared to Malaysia's forces such as the uses of GPS, engine up to 400 horsepower, communicator etc. (Che Moin Umar, 2002 and Briefing by APMM, 2014).

The situation becomes even more challenging given Sabah's close proximity to neighbouring countries in facing domestic problems like Indonesia and Philippines. When describing this factor, the former Sabah Police Commissioner, Ramli Yusuf said 'Sabah was most difficult .... Every state is unique and perhaps Sabah is more unique than the rest due to its proximity to the conflict in southern Philippines' (Daily Express (Sabah), 18 January 2004). Due to its proximity, it is said that from certain parts of Sabah, it only takes a few minutes by boat to reach Philippine or Indonesian waters such as the area in Tanjung Labian (Lahad Datu), Tambisan (Sandakan), Pulau Mataking (Semporna), Sebatik (Tawau), Serudung (Tawau) etc. In Semporna for example, it would take just a few minutes on a speedboat to escape from Sabah into Sitingkai Island of the Southern Philippines and around 15 minutes (more or less $5 \mathrm{~km}$ ) from Mataking Island on Semporna to the nearest island in the Philippines water (Ramli Dollah et. al. 2003). Sibutu, Taganak, Bongao, Mengesee, Balabac, and Cagayan are provinces in Southern Philippines which are very close to Malaysia territory. Tawi-Tawi Island in the Philippines for example is said to be only 27 nautical miles from the Sabah's shore, making it plainly visible from Tanjung Labian in Lahad Datu (Wan Shawaluddin Wan Hassan et. al, 2010). One such example of this could be seen in April 2003 when 22 Filipino who were suspected members of Jl or other terrorist groups were arrested on 27 April 2003 near Sandakan, Sabah. It was reported that they were found to be carrying explosives and ammunition. Later, they were released because it was proved that this group was not a Jl or militia members but a group of villagers who were heading for a wedding celebration in the southern Philippines and had unintentionally strayed into Sabah waters. It was also proved that they had bought the explosive and ammunition because it was customary in their village to shots in the air during celebrations (Borneo Mail, 12 May 2003).

Another challenge is the presence of stateless people or sea-nomads (or known as Palau among locals) which is often seen as a major constraint in addressing the cross-border issue, and a cause for concern for Malaysian authorities. Today, this group is estimated to number around tens of thousands and roam freely around the east coast of Sabah and the Philippines. They can be found in several areas such as Kudat, Sandakan, Lahad Datu and Semporna. The main problem that arises is that the fact that their ancestor has been dwelling this area, much longer than the concept of the border in Sabah. In fact, it should be recognized that this marginalized group is only being taken care of by the authorities when it comes to security issues, as happen after the Tanduo incident. Therefore, this situation makes it difficult to deal with this issue and it needs further research in order to manage this person effectively.

Another very important issue in discussing the problems that occur are related to law, peace and security in the southern Philippines. Security should be seen as a coin with two sides and each requires one to another. Therefore, security cannot be achieved without peace, order and economic development. With regard to this issue, this paper argues that as long as peace, law and order together with economic development cannot be restored in the southern Philippines, the problem of cross-border crime will continue to be a serious threat for Malaysia, and Sabah in particular. 


\section{Conclusion}

From this discussion, it is clear that Sabah security, especially in the eastern coast of Sabah is a very complex issue, not only due to the nature of threats itself, but also having to take into consideration other issues such as geographical factor as well as humanitarian issues. The Malaysian government, especially enforcement agencies should understand that these new threats cannot be managed by traditional or military approach alone because it requires a comprehensive and holistic approach to include the non-military approach. For Sabah, especially in the eastern part of Sabah, the key lesson is that the threats posed cannot be controlled by tightening the border security or increasing the number of military or police policing the border. Instead, the government should focus more on 'soft approaches' such as utilizing and empowering the role of the Institution of Village Security and Development Committee (JKKK), empowering the role of religious institution at the village level; engaging and educating border communities on their roles in strengthening national sovereignty; restoring peace, law and order as well as economic development in the southern Philippines and so on. It is also the reason why several Malaysian politicians since the 1990s, among them Sabah's former chief Minister, Yong Teck Lee, suggested the concept of 'prosper thy neighbors' as an alternative to reduce the influx of migrants and other cross-border problems into this country. It was pursued through the involvement of Malaysia in the peace process in Mindanao and at the same time promoting the Indonesia and Southern Philippines to Malaysian investor.

\section{Acknowledgement}

This article is based on the exploratory research grant (ERGS0018-PK-1/2012) funded by the Ministry of Higher Education, Malaysia. The authors wish to thank the Universiti Malaysia Sabah, Ministry of Higher Education, Malaysia and those supporting this study. We thank to anonymous referee of this journal for their encouragement, criticism and valuable suggestion.

\section{References}

"Esszone: Curfew extended to March 29", The Star, 14 March

Abuza, Zachary (2003) Funding Terrorism in Southeast Asia: The Financial Network of Al Qaeda and Jemaah Islamiyah, NBR Analysis, December 2003.

Andaya, Barbara \& Leonard Andaya (2001), A History of Malaysia, Honolulu: University of Hawaii Press.

Asis, Maruja M.B., (2005) The Filipinos in Sabah: Unauthorised, unwanted and unprotected in Santosh Jatrana; Mika Toyota; Brenda S. A. Yeoh (Eds.), Migration and Health in Asia (pp. 116-140), London: Routledge.

Astro Awani (2014) Satu Lagi Kes Penculikan Berlaku di Kawasan Pantai Timur Sabah [Another kidnapping case in East Coast of Sabah], Astro Awani, 29 Sept

Ayoob, Mohammed (1995) The Third World Security Predicament: State Making, Regional Conflict and the International System, Boulder/London: Lynne Rienner

Azar, Edward and Chung-In Moon (1984) Third World National Security: Toward A new conceptual framework, International Interactions, $11(2), 103-135$.

Azar, Edward., and Moon (1988) 'Legitimacy, Integration and Policy Capacity: The 'Software' side of Third World National Security' in Azar and Moon (Eds.), National Security in the Third World, Aldershot: Edward Elgar.

Azizah Kassim (Ed.), (2004) Proceeding of Public Responses to Foreign Workers in Sabah, Kota Kinabalu: UPEP

Baldwin, David (1995), Security Studies and the end of the Cold War, World Politics, 48 (1), 117-141.

Berita Harian (1996) MNLF jamin terima semua pelarian [MNLF guarantees welcome to refugees], Berita Harian, 23 Sept.

Berita Harian, (1996) Misuari jamin keselamatan pelabur [Misuari guarantees investors security], Berita Harian, 25 Oct.

Borneo Post (2013) Security area to be called Esscom, Borneo Post, 12 March

Borneo Post, (2015) Curfew in ESSZone extends till Nov 25, Borneo Post, 9 November

Business Times (1996) Investment potential, Business Times, 02. October;

Buzan, Barry et. al, (1998) Security: A New Framework for Analysis, Boulder: Lynne Rienner.

Buzan, Barry, (1991) People, States, and Fear: An Agenda for International Security Studies in the Post-Cold War Era (2nd edition), Boulder: Lynne Rienner

Collins, James, Ramli Dollah \& Zaini Othman (2015), Pengaruh Persekitaran Fizikal Geografi Terhadap Keterancaman Persempadanan Pantai Timur Sabah [Influence of Physical Geography on border security in East Coast of Sabah.], paper presented at Seminar Malaysia-Indonesia dalam Perspektif Sempadan Sabah 2015[2015 Malaysia-Indonesia through the border perspective Seminar]. YTL Hall, UMS, 23 April.

Daily Express (2013) Najib on 4 aspects Esscom cannot compromise on, Daily Express (Sabah), 14 Apr.

Daily Express (2008) Deportees declare they will return to Sabah", Daily Express (Sabah), 25 July.

Daily Express (2008) Deportees mostly back in two weeks, Daily Express (Sabah), 09 July 2008. 
Daily Express (2008) Hypocrisy on illegal issue: Marsidi, Daily Express (Sabah), 11 July.

Harian Metro (2014) Penculikan di pantai timur Sabah: Muhyiddin kecewa dah labur RM300 juta pada ESSCOM, keselamatan Sabah masih terancam [Kidnappings in east coast of Sabah: Muhyiddin regrets Sabah's security still threatened despite RM300 million investment in ESSCOM], Harian Metro, 29 September.

Holsti, Kalevi. (1995) War, peace, and the state of the state, International Political Science Review, Vol. 16 (4), 331-332.

Interview with Datuk Ramli Yusuff, Daily Express (Sabah), 18 January 2004

Karim Ghani, Dewan Negara [The Senate, the upper House of the Parliament of Malaysia], 12 November 2003

Katzenstein, Peter (Ed.) (1996) The Culture of National Security, New York: Columbia University Press

Kolodziej, Edward, (1992) Renaissance in Security Studies? Caveat Lector!, International Studies Quarterly, Vol. 36 (4), 421-438;

Lumayag-Too, (2004) Negotiating A World Without Borders: Narratives of Powerlessness and Resistance of Filipino Migrants in Malaysia, paper presented at International Bajau Sama Communities, UMS, 21-23 July;

Mandel, Robert (1994), The changing face of national security: A conceptual analysis, Westport: Greenwood Press

Mohd Kassim Noor Mohamed (2008), Kidnap for Ransom in South East Asia. The case for a Regional Recording Standard, Asian Criminology, 2008, 3, 61-73.

Mohd Najib Tun Haji Abdul Razak (2014), 2015 National Budget, (Dewan Rakyat, 10 Oktober)

Morgenthau, Hans (1960), Politics among Nations. The Struggle for Power and Peace, 3rd edition, New York: Alfred Knopf

New Sabah Times (2002) Maklumat bocor[Information Leaked], New Sabah Times, 05 February.

New Straits Times (1996) 25 deals signed with Mindanao companies, New Straits Times, 28 Oct.

New Straits Times (1996), Flights, more ferry links to Mindanao, New Straits Times, 03 Dec.

New Straits Times, (1996) Malaysia welcomes pact signed by the Philippines, MNLF, New Straits Times, 03 Sept.

New Straits Times, (1996), Misuari: We'll welcome home Filipinos in Sabah, New Straits Times, 23 Sept.

Philippines daily inquirer (2008), For deported Filipinos: It's Sabah or bust" Philippines daily inquirer, 24 July

Ramli Dollah and Ahmad Mosfi Mohamad (2007), Perdagangan Tukar Barang Tawau (Sabah)-Indonesia: Implikasi dan Cabaran (Tawau-Indonesia's Barter Trade: Implications and Challenges), JATI: Journal of Southeast Asian Studies, 12, 171-188

Ramli Dollah \& Mohd Zambri Suharani (2015). "Fungsi dan Peranan ESSCOM dalam Menjamin Keselamatan Sabah: Satu perbandingan Persepsi antar Komuniti 'Luar' dan Komuniti ESSZONE" [Role \& Function of ESSCOM in securing Sabah: A Comparative perspective between Outside community and ESSZONE Community], Jurnal Komunikasi Borneo[Borneo Communications Journal], 2, 1-28.

Ramli Dollah. (2004) Lanun ATAU Mundu di Sabah?[Pirates or Mundu in Sabah], JATI: Journal of Southeast Asia Universiti Malaya, 9 , 171-188.

Ramli Dollah, Wan Shawaluddin W. Hassan, Diana Peters \& Marja Azlima Omar (2003) 'Pendatang Islam Filipina di Sabah: Satu Pemerhatian dari Sudut Keselamatan [Muslim Filipino migrants in Sabah: A study from the security perspective]', JATI: Jurnal Jabatan Asia Tenggara [Journal of Southeast Asia] Universiti Malaya, 8. December, 217-240.

Sather, Clifford (1997), The Bajau Laut: Adaptation, History And Fate In A Maritime Fishing Society Of Southeastern Sabah, Singapore: Oxford University Press

Sopher, David (1981), Nomadic Boat People, in Nagasura T. Madale (Ed.) The Muslim Filipinos, Philippines: Alemar Phoenix Publishing House, 1981

Stephen Walt, (1991) The Renaissance of Security Studies, International Studies Quarterly, 35 (2), 211-239

Storey, Ian (2008), Securing Southeast Asia's Sea Lanes: A Work in Progress, Asia Policy, 6, December 2008, 95-128.

Syed Hamid Albar, [Home Minister] (2008), Dewan Rakyat [House of Representatives, the Lower House of the Parliament of Malaysia], 27 August.

Teriff, Terry et. al, (1999) Security Studies Today, Cambridge: Polity Press

Thayer, Carl (2003) Political Terrorism in Southeast Asia, Pointer: Quarterly Journal of the Singapore Armed Forces, 2003, http://www.mindef.gov.sg/content/imindef/publications/pointer/journals/2003/v29n4/features/feature5.html

The Borneo Insider (2013) ESSCOM, ESSZONE not a vote-fishing scheme, The Borneo Insider, 3 April

The Rakyat Post (2014) Taiwan Media: Chang An-wei's Family Paid RM800,000 Ransom, The Rakyat Post, 21 Dec 2014, http://www.therakyatpost.com

The Star (2013) Life goes on in Pom Pom, The Star, 18 November

The Star (2014) Zahid: Foreign vessels to follow designated routes off east coast of Sabah, The Star, 07 May

Tregonning, K. G, (1965) History of Modern Sabah, 1881-1963, Kuala Lumpur: University of Malaya Press

Ullman, Richard, (1983) Redefining Security, International Security, 8, 129-135

Utusan Borneo (2003) Rondaan 24 jam ATM awasi perairan Sabah [24 hour patrols by ATM to monitor Sabah waters], Utusan Borneo, $14 \mathrm{Mar}$.

Vanar, Muguntan, (2014) Esszone curfew extended till Jan 9, The Star, 24 Dec.

Warren, James (1985), The Sulu Zone 1768-1898, Philippine: New Day Publisher

Warren, James (2002), Irranun and Balangingi: Globalization, Maritime Raiding and the birth of Ethnicity, Singapore: Nyanyang University Press 